\title{
Effect of Canal Bank Filtration on Quality of Water Long Hyderabad City
}

\author{
IMDAD ALI KANDHAR*, GHOUS BUX KHASKHELI*, ABDUL RAZAQUE SAHITO**, AND \\ RASOOL BUX MAHAR** \\ RECEIVED ON 09.02.2016 ACCEPTED ON 11.05.2016
}

\begin{abstract}
The focus of the present study was to examine the effect of canal bank filtration on the quality of water and the geological settings along the banks of canals at the shallow depth aquifers. The four Model wells were drilled at different locations of the Line channel, Pinyari and phulali canals in the study area. The samples of soil were collected throughout drilling of the model wells for the analysis of grain size distribution .In addition to this, canal water and model well water samples were collected and analyzed for the water quality characteristics during winter and summer seasons. The analysis of soil and water samples reveals that the ground water is influenced by the grain size distribution, hydraulic conductivity and the location of the model Wells. The model well that has higher percentage of $0.075 \mathrm{~mm}$ of grain size distribution(hydraulic conductivity between 10-25 ft/day) was more suitable for the filtration of the canal water through its banks, followed by $\mathbf{0 . 1 5} \mathbf{m m}$ of grain size distribution (hydraulic conductivity $>\mathbf{2 5 \mathrm { ft } /}$ day). Moreover, the present study also shows that the canal water filtration is suitable in terms of total alkalinity, nitrate-nitrogen, total iron and $\mathrm{pH}$ to get the potable water at the location near upstream of the canal, especially in the summer season.
\end{abstract}

Key Words: Bank Filtration, Grain Size Distribution, Water Quality, Permeability.

\section{INTRODUCTION}

The water is vital for survival of life on the earth [1]. Water is everywhere, but most of it is not fit for drinking, cooking, washing and for other domestic needs. Water is an important substance of life, survival of life without water is impossible on earth. We receive fresh water through hydrological cycle; water evaporates from oceans/surface water bodies and transpiration from plants, it becomes cloudy in the atmosphere, it rains and makes surface water, such as rivers, lakes, reservoirs and finally leads to the oceans. Infiltration of rain water or surface water makes an aquifer, where water is stored in the voids in the soil and is known as groundwater [2]. The surface and groundwater sources have different characteristics and may be useful for domestic needs directly or by providing a suitable treatment. Water containing physical, chemical or biological pollutants need to bring its concentration within WHO (World Health Organization) guidelines for drinking water [3] .

* Department of Civil Engineering, Mehran University of Engineering \& Technology, Jamshoro.

** Institute of Environmental Engineering \& Management, Mehran University of Engineering \& Technology, Jamshoro.

Mehran University Research Journal of Engineering \& Technology, Volume 35, No. 3, July, 2016 [p-ISSN: 0254-7821, e-ISSN: 2413-7219] 
Water and sanitation are a prime issue of the developing countries like; Pakistan, where water resources are deteriorating due to the environmental pollution. The urbanization, industrialization and the growth of population in developing countries is increasing. The water shortage and water pollution control are beyond the demand of water in economical poor countries [4]. Increasing water demand is a big issue at present and for future in Pakistan, so that, each watershed should be considered as a management unit, which should be protected from the pollution. The water treatment methods may be conventional such as slow sand filtration, rapid sand filtration, and Vacuum filtration or through advance methods of treatment. Those methods of water treatment filtration have some limitations to produce the hygienic water quality [5]. The systems require huge amount and trained manpower to operate the water filtration unit/plant. Developing nations do not bear the burden of water demand and sanitation [6].

The other method of surface water treatment is natural purification and is known as RBF (Riverbank Filtration) [7]. RBF is more economical and easy to operate so called the augment technology for the drinking water production [8]. The quality of surface water is frequently exaggerated by runoff of agricultural land, effluents from industries and municipal wastewaters, while the bank filtration substantially improves the quality of water [9]. During the process of bank filtration surface water infiltrate, travels to the aquifer through the pores soil passage various pollutants of surface water are removed and or reduced, such as suspended solids, microorganisms and the chemicals are reported in various studies [10-13]. The RBF method can be applied where the river, stream, channels, or the stagnant water bodies such as lakes and the reservoirs are available near to the abstraction wells. The produced water through a bank filtration process almost meets the WHO guideline values for drinking water standards [3].Various studies around the world have been conducted on the RBF processes; the findings are reported and have shown improvement in surface water treatment, the removal, or reductions in the concentration of water pollutants during the infiltration process of surface water towards the abstraction wells near to the surface water bodies. This natural water filtration process is similar to the slow sand filtration process for drinking water treatment.

$\mathrm{RBF}$ is dependent on relations between surface water and groundwater. When surface water enters the groundwater system through infiltration, some of the contaminants in the surface water may be removed through the percolating process of moving through the sediment, and it can result in an overall improvement in water quality [14]. RBF can reduce contaminant levels in groundwater through physical filtering, microbial degradation, an ion exchange, precipitation, and sorption processes [15]. In contrast to utmost groundwater resources, sandy aquifers, which are hydraulically associated to rivers are usually at ease to exploit and are extremely productive for drinking water deliveries [16]. The geological settings of the aquifer play an important role in the production of filtered or treated water quality. The environmental conditions of the study area is counted as semi-arid region of the country, where the underground water contains higher concentrations of the geochemical total dissolved solids making underground water source unfit for the domestic needs.

In this piece of research work, the effect of canal bank water filtration was analyzed over the quality of water under the local environmental and geological conditions of Hyderabad. Bank filtration parameters related to geological settings of the aquifer, such as grain size distribution, hydraulic conductivity, depth of shallow aquifer related to the distance from the river bank and head race to the model wells were analyzed. Moreover, canal surface water and ground water from model wells were analyzed for water quality during high-flow (summer) and low-flow (winter) seasons of the year and its impact on the quality of water was analyzed under local environmental conditions of the Hyderabad city. The physiochemical characteristics of treated water through bank filtration were also compared to WHO guideline for drinking water. 


\section{METHODOLOGY}

\subsection{Study Area}

The study area of the present study is canals near the Hyderabad as shown in Fig. 1. These canals are off-taking from up-stream of Kotri barrage, and are crossing the Hyderabad city. It belongs to the semi-arid regions of Pakistan, its groundwater is saline in nature [2]. Most of the drinking water in Hyderabad city is supplied by the conventional water treatment plants, which receives raw water from Indus River. The alternative source of domestic water in the study area is the RBF, where private bore wells are installed along the banks of canals. In order to understand the local geological settings of the model wells, four model wells, i.e., MW-01, MW-02, MW-03, and MW-04 were drilled through at the points as shown in Fig. 1. The depth of the Model Wells was in the order of $50,55,65$ and $75 \mathrm{ft}$. respectively.

\subsection{Collection and Physical Analysis of Soil Samples}

The soil core samples were prepared by taking five samples from each 5 feet of the model wells, which were mixed thoroughly in a bucket to make one composite sample. The samples of the soil were collected and transferred in the polyethylene bags and labeled for the further laboratory analysis. The physical analysis of the soil samples included the grain size distribution, which was carried out by applying ASTM methods of sieving [17]. The stack of the sieves was selected for the medium to fine sand particles such as $425,295,150,75 \mu \mathrm{m}$ and $<75 \mu \mathrm{m}$. The analysis of model well sediment samples conducted for grain size and their distribution in each strata layer vertically for understanding the behavior of the filter bed material in particular depth of the shallow aquifer.Moreover, the hydraulic conductivity was estimated by using Equation (1) [18].

$\mathrm{K}=\mathrm{C} \cdot \mathrm{D}^{2}{ }_{10}$

Where, $\mathrm{K}$ is the hydraulic conductivity in $\mathrm{ft} /$ day, $\mathrm{C}$ is the constant and is equal to 100 , and $\mathrm{D}_{10}$ is the effective size of particles corresponding to $10 \%$ passing taken in $\mathrm{cm}$.

\subsection{Collection and Chemical Analysis of Water Samples}

In order to analyze the quality of the surface water from the canals and ground water from the Model Wells, grab samples were collected from each source for onsite and laboratory analysis of the physiochemical concentration

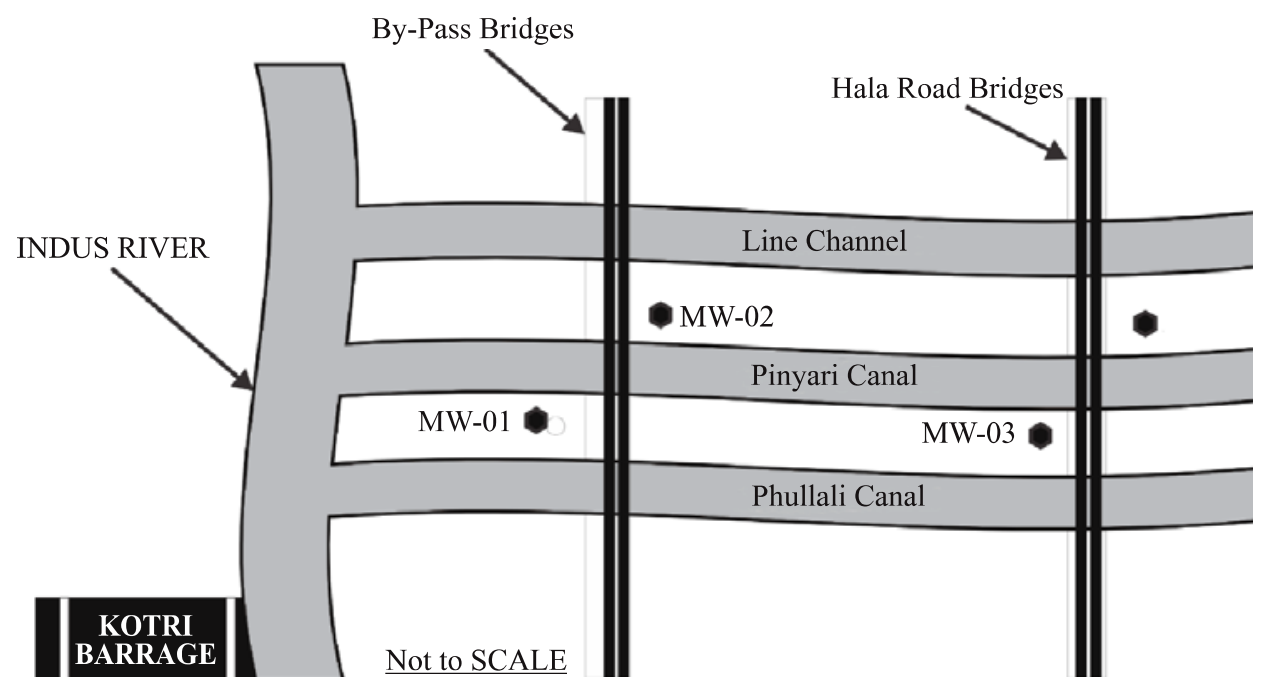

FIG. 1. LOCATION OF THE MODEL WELLS IN THE STUDY AREA

Mehran University Research Journal of Engineering \& Technology, Volume 35, No. 3, July, 2016 [p-ISSN: 0254-7821, e-ISSN: 2413-7219] 
during the summer and winter seasons of the year. The surface water samples were collected from different depth at first from the surface below $3 \mathrm{ft}$., second from the middle and third from the bottom above 2-3ft. All the three samples were mixed in a bucket to make one composite sample of water. The ground water samples were collected from the Model Wells at the designated depths stated above. All samples were collected in prewashed plastic bottles. During the summer season, collected samples were preserved in the ice containing sampling box.

The surface water and ground water samples were analyzed for canal water and Model Wells for the evaluation of bank filtration impact on water quality under local geological settings, river and MW water samples were collected and analyzed for the parameters according to the standard methods of water and wastewater examination [19], except $\mathrm{pH}$ and are listed in Table 1. The water samples from the canal and model wells were collected during the summer and winter seasons of the year. The selected water quality parameters were applied to analyze the water samples of river water and model wells and include alkalinity, nitrates, total dissolved solids, chloride, sulfate, total iron content and $\mathrm{pH}$ of water. These parameters and their concentrations are also compared with WHO guideline values for drinking water [3].

\section{RESULTS AND DISCUSSIONS}

\subsection{Grain Size Distribution of Soil}

\subsubsection{Grain Size Distribution for MW-01}

The percentage of vertical grain size distribution and hydraulic conductivity of MW-01 is given in Table 2, whereas its curve is shown in Fig. 2. As per the results, the grains greater than $0.075 \mathrm{~mm}$ were dominant over the grain size less than $0.15 \mathrm{~mm}$ vertically from $25-50 \mathrm{ft}$. The average grains percent distribution was 14 and $75 \%$ of grain size less than $0.15 \mathrm{~mm}$ and greater than $0.075 \mathrm{~mm}$, respectively. Medium to fine sand was dominant up to the $50 \mathrm{ft}$. of depth. Below the $45 \mathrm{ft}$. the trend of distribution was changed as the grains less than $0.15 \mathrm{~mm}$ were $68 \%$ and grains greater than $0.075 \mathrm{~mm}$ were $29 \%$, while the particles less than $0.075 \mathrm{~mm}$ were $2-7 \%$ distributed vertically. The sand-silt mixture average $23 \%$ were found in the stratum of $40-45 \mathrm{ft}$.

Moreover, the grain size of the MW-01 vertical distribution trend shows the stratum of the bore well soil in $35-40 \mathrm{ft}$. containing higher percentage of 0.425 and $0.075 \mathrm{~mm}$ size of grains, according to their values as 0.52 and $87.86 \%$, which was decreased from $40-50 \mathrm{ft}$. as from $0.24 \%$ and $29.49 \%$ respectively. The grain size less than $0.075 \mathrm{~mm}$ particles $23.2 \%$ was found higher at $40-45 \mathrm{ft}$. compared to the 25-50ft. of the stratum of the bore well. The hydraulic conductivity was in the range of 10.37-25.97 ft/day. The

TABLE 1. CHEMICAL PARAMETERS OF WATER SAMPLES ALONG WITH STANDARD METHODS

\begin{tabular}{|c|c|c|c|}
\hline No. & Chemical Parameter & Standard Method & Method No. \\
\hline 1. & Total Alkalinity $\left(\mathrm{CaCO}_{3}\right)$ & Titration Method & $2320 \mathrm{~B}$ \\
\hline 2. & Nitrate-Nitrogen $\left(\mathrm{NO}_{3}-1\right)$ & Cadmium Reduction Method & EC Meter \\
\hline 3. & Total Dissolved Solids & Conductivity Method & $4500 \mathrm{~B}$ \\
\hline 4. & Chlorides $(\mathrm{Cl}-1)$ & Argentometric Method & 8051 \\
\hline 5. & Sulfates $\left(\mathrm{SO}_{4}-2\right)$ & 1 Turbidity Method & 8008 \\
\hline 6. & Iron Total $(\mathrm{Fe}+2)$ & Potentiometric Method & $\mathrm{pH} \mathrm{Meter}$ \\
\hline 7. & $\mathrm{pH}$ & & \\
\hline
\end{tabular}

Mehran University Research Journal of Engineering \& Technology, Volume 35, No. 3, July, 2016 [p-ISSN: 0254-7821, e-ISSN: 2413-7219] 
hydraulic conductivity at the top surface is higher but decreases as the depth increases, except for the depth of 40 and $50 \mathrm{ft}$. This decrease in the hydraulic conductivity is because of the higher percentage of the small particles i.e. silt and clay.

\subsubsection{Grain Size Distribution for MW-02}

The percentage of vertical grain size distribution and hydraulic conductivity of MW-02 is given in Table 3, whereas its curve is shown in Fig. 3. Through the physical analysis of the MW-02, it was found that the grain size $4.75,2.0$ and $0.425 \mathrm{~mm}$ size particles were found up to $100 \%$ from $25-65 \mathrm{ft}$. The $0.15 \mathrm{~mm}$ grain size of the particles was increased in percent passing value as $48-90 \%$ from 25 $45 \mathrm{ft}$., while percent distribution decreased from 50-65ft. as $90-23 \%$ vertically. The maximum percentage of the grain of $0.075 \mathrm{~mm}$ size was $15-19 \%$ from $25-40 \mathrm{ft}$. which was further decreased from $19-1.3 \%$ distribution vertically, where the $0.15 \mathrm{~mm}$ grains were increased within $50-65 \mathrm{ft}$. The hydraulic conductivity was in the range of $12.15-28.80 \mathrm{ft} / \mathrm{day}$. The hydraulic conductivity at the top surface is lower but increases as the depth increases, except for the depth of 40-45 ft. This decrease in the hydraulic conductivity is because of the higher percentage of the small particles i.e. silt and clay.

TABLE 2. VERTICAL GRAIN SIZE DISTRIBUTION AND HYDRAULIC CONDUCTIVITY OF MW-01

\begin{tabular}{|c|c|c|c|c|c|c|}
\hline \multirow{2}{*}{$\begin{array}{l}\text { Depth } \\
\text { (ft) }\end{array}$} & \multicolumn{4}{|c|}{ Sieve Opening Size (mm) } & \multirow{4}{*}{$\begin{array}{c}\mathrm{D}_{10} \\
(\mathrm{~mm})\end{array}$} & \multirow{4}{*}{$\begin{array}{c}\mathrm{k} \\
\text { (ft/day) }\end{array}$} \\
\hline & 0.425 & 0.15 & 0.075 & $<0.075$ & & \\
\hline 0 & \multirow{2}{*}{\multicolumn{4}{|c|}{ Vertical Grain Size Distribution (\%) }} & & \\
\hline 25 & & & & & & \\
\hline 30 & 0.34 & 16.44 & 75.78 & 7.44 & 0.08 & 23.33 \\
\hline 35 & 0.2 & 15.20 & 78.45 & 6.15 & 0.085 & 20.79 \\
\hline 40 & 0.52 & 7.11 & 87.86 & 4.51 & 0.085 & 20.79 \\
\hline 45 & 0.3 & 18.40 & 58.10 & 32.20 & 0.06 & 10.37 \\
\hline 50 & 0.24 & 68.05 & 29.49 & 2.22 & 0.095 & 25.97 \\
\hline
\end{tabular}

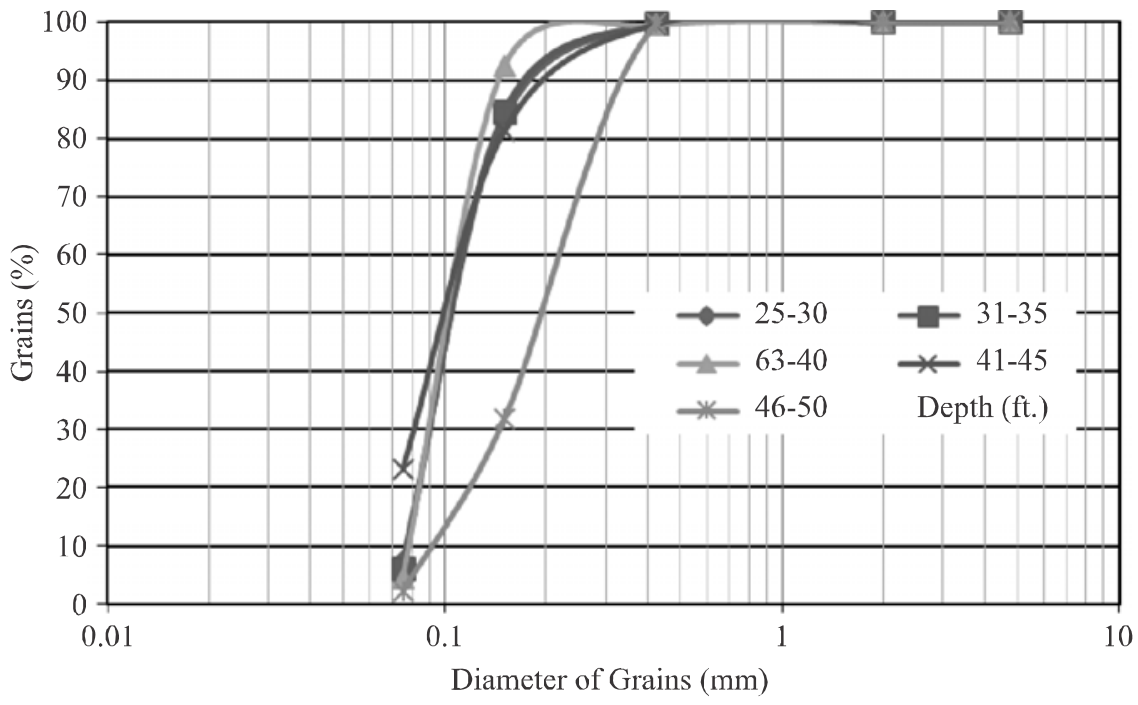

FIG. 2. GRAIN SIZE DISTRIBUTION CURVE FOR MW-01 


\subsubsection{Grain Size Distribution for MW-03}

The percentage of vertical grain size distribution and hydraulic conductivity of MW-02 is given in Table 4, whereas its curve is shown in Fig. 4. The MW-03, sediments represent the trend of the particle size 4.75 and $2.0 \mathrm{~mm}$ were found around $100 \%$ of the $30-55 \mathrm{ft}$, and $0.425 \mathrm{~mm}$ were decreased $98-50 \%$ from $30-55 \mathrm{ft}$. vertically. Grain sized $0.15 \mathrm{~mm}$ was around $50 \%$ at the $25-30 \mathrm{ft}$. stratum, which was decreased up to $10 \%$ at the $55 \mathrm{ft}$. of the stratum of the bore well. The grain size $0.075 \mathrm{~mm}$ were found within the range of $4.8-1.33 \%$ through the vertical distribution of 30-55ft. The hydraulic conductivity was in the range of $25.45-56.45 \mathrm{ft} / \mathrm{day}$. The hydraulic conductivity at the top surface is lower but increases as the depth increases and slightly decreases at the depth of $55 \mathrm{ft}$. This change is mainly because of the higher percentage of the $0.15 \mathrm{~mm}$ grain size distribution.

TABLE 3. VERTICAL GRAIN SIZE DISTRIBUTION AND HYDRAULIC CONDUCTIVITY OF MW-02

\begin{tabular}{|c|c|c|c|c|c|c|}
\hline \multirow{2}{*}{$\begin{array}{l}\text { Depth } \\
\text { (ft) }\end{array}$} & \multicolumn{4}{|c|}{ Sieve Opening Size (mm) } & \multirow{4}{*}{$\begin{array}{c}\mathrm{D}_{10} \\
(\mathrm{~mm})\end{array}$} & \multirow{4}{*}{$\begin{array}{c}\mathrm{k} \\
\text { (ft/day) }\end{array}$} \\
\hline & 0.425 & 0.15 & 0.075 & $<0.075$ & & \\
\hline 0 & \multirow{2}{*}{\multicolumn{4}{|c|}{ Vertical Grain Size Distribution (\%) }} & & \\
\hline 25 & & & & & & \\
\hline 30 & 0.45 & 52.60 & 34.98 & 11.97 & 0.075 & 16.19 \\
\hline 35 & 0.42 & 5.18 & 84.60 & 9.80 & 0.075 & 16.19 \\
\hline 40 & 0.36 & 6.40 & 37.60 & 19.64 & 0.065 & 12.15 \\
\hline 45 & 0.33 & 14.02 & 71.34 & 14.28 & 0.07 & 14.11 \\
\hline 50 & 0.24 & 5.35 & 84.80 & 9.61 & 0.075 & 16.19 \\
\hline 55 & 0.21 & 61.76 & 33.37 & 4.66 & 0.085 & 20.82 \\
\hline 60 & 0.32 & 77.93 & 19.41 & 2.34 & 0.09 & 23.33 \\
\hline 65 & 0.33 & 77.70 & 20.68 & 1.29 & 0.1 & 28.0 \\
\hline
\end{tabular}

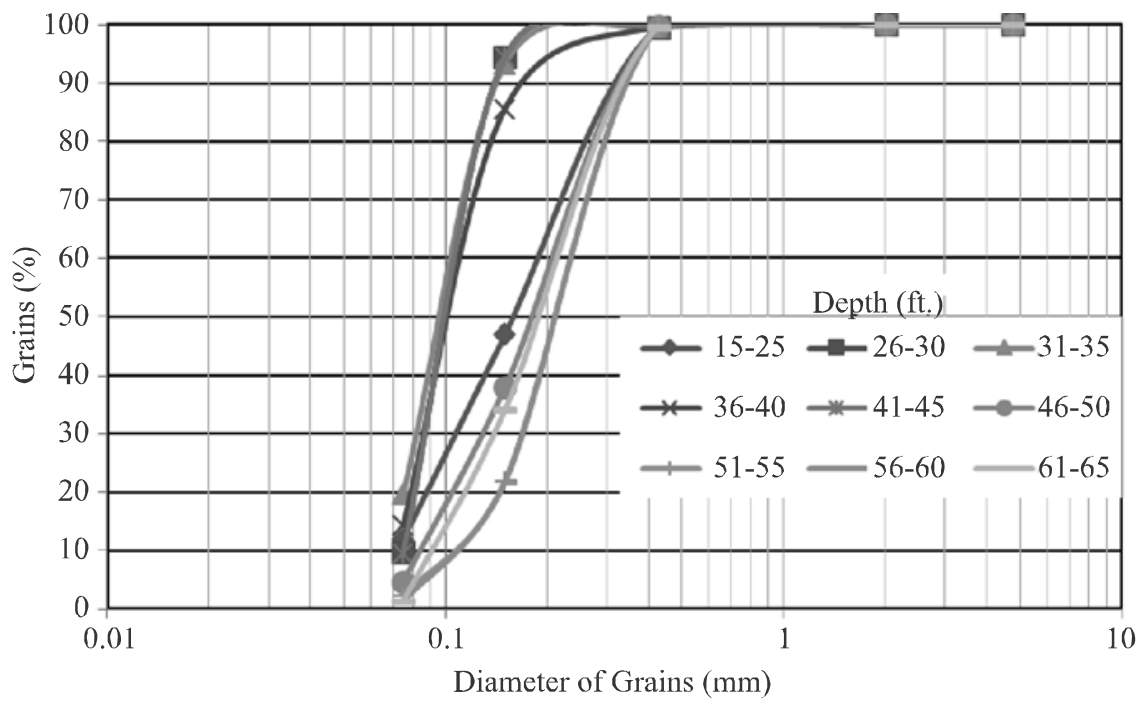

FIG. 3. GRAIN SIZE DISTRIBUTION CURVE FOR MW-02 


\subsubsection{Grain Size Distribution for MW-04}

The percentage of vertical grain size distribution and hydraulic conductivity of MW-02 is given in Table 5, whereas its curve is shown in Fig. 5. The vertical grain size distribution of MW-04 represents that the 4.75 and $2.0 \mathrm{~mm}$ size grained were distributed around $100 \%$ from $25-75 \mathrm{ft}$. vertical stratum of the bore well sediments. The $0.425 \mathrm{~mm}$ sized grains were decreased $45-55 \mathrm{ft}$., and at the depth of $60 \mathrm{ft}$. stratum it was found up to $100 \%$. The grain size $0.15 \mathrm{~mm}$ was $50-90 \%$ from $25-45 \mathrm{ft}$. The $0.075 \mathrm{~mm}$ grain distribution was 23-1.3\%, from 25-75ft. vertically decreased. The hydraulic conductivity was in the range of 12.15-64.80 ft/day. The hydraulic conductivity at the top surface is lower but increases as the depth increases. Lower hydraulic conductivity is because of the clogging of the canal sediments [20].As compared to the MW-03, the MW-04 allow less quantity of the water to pass through.

TABLE 4. VERTICAL GRAIN SIZE DISTRIBUTION AND HYDRAULIC CONDUCTIVITY OF MW-03

\begin{tabular}{|c|c|c|c|c|c|c|}
\hline \multirow{2}{*}{$\begin{array}{l}\text { Depth } \\
\text { (ft) }\end{array}$} & \multicolumn{4}{|c|}{ Sieve Opening Size (mm) } & \multirow{4}{*}{$\begin{array}{c}\mathrm{D}_{10} \\
(\mathrm{~mm})\end{array}$} & \multirow{4}{*}{$\begin{array}{c}\mathrm{k} \\
\text { (ft/day) }\end{array}$} \\
\hline & 0.425 & 0.15 & 0.075 & $<0.075$ & & \\
\hline 0 & \multirow{2}{*}{\multicolumn{4}{|c|}{ Vertical Grain Size Distribution (\%) }} & & \\
\hline 25 & & & & & & \\
\hline 30 & 0.72 & 49.90 & 46.02 & 3.37 & 0.094 & 25.45 \\
\hline 35 & 3.13 & 76.55 & 16.33 & 3.99 & 0.12 & 41.52 \\
\hline 40 & 4.91 & 74.67 & 15.58 & 4.84 & 0.12 & 41.2 \\
\hline 45 & 10.90 & 73.37 & 14.40 & 1.33 & 0.15 & 64.8 \\
\hline 50 & 46.46 & 46.09 & 5.34 & 2.11 & 0.15 & 64.8 \\
\hline 55 & 38.42 & 51.26 & 7.05 & 3.37 & 0.14 & 56.45 \\
\hline
\end{tabular}

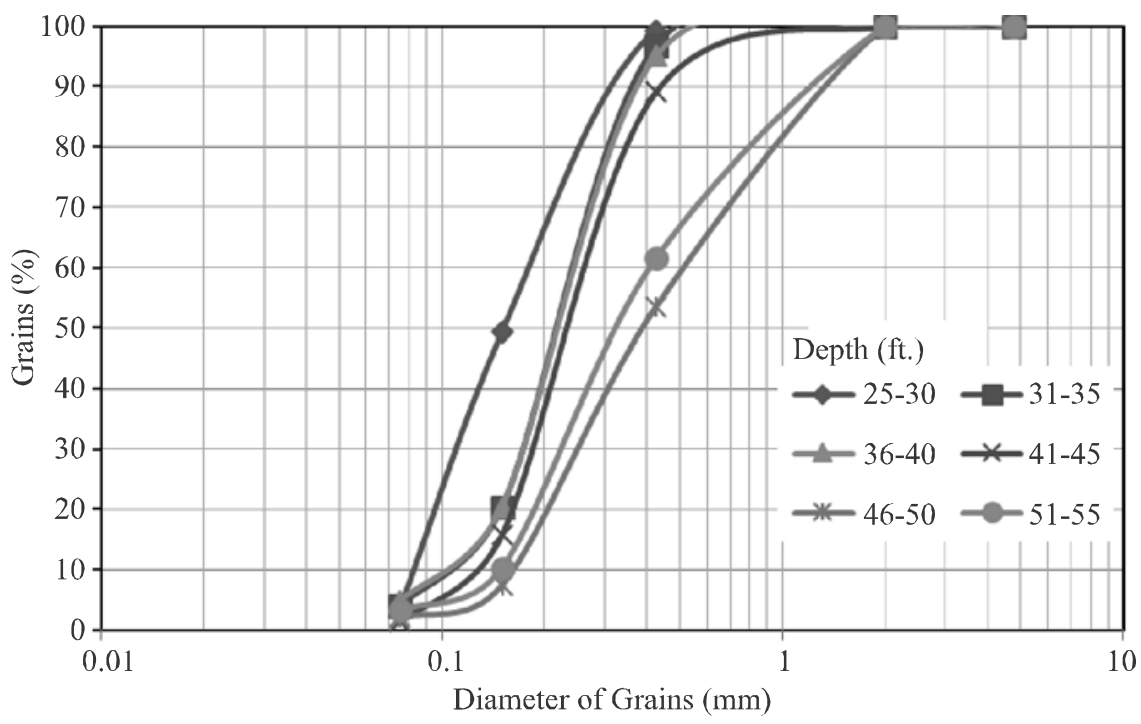

FIG. 4. GRAIN SIZE DISTRIBUTION CURVE FOR MW-03 


\subsection{Chemical Analysis of Canal and Model Wells' Water}

\subsubsection{Alkalinity}

The alkalinity of normal waters is because of the salts of fragile acids, while fragile or tough bases can also add in the alkalinity. Bicarbonate signifies the chief form of alkalinity, subsequently it is made in substantial quantities by the action of carbon dioxide upon basic ingredients in the soil.

The concentration of the alkalinity in canal water and ground water during the summer and winter seasons is shown in Fig. 6. The alkalinity of the canal surface water

TABLE 5. VERTICAL GRAIN SIZE DISTRIBUTION AND HYDRAULIC CONDUCTIVITY OF MW-04

\begin{tabular}{|c|c|c|c|c|c|c|}
\hline \multirow{2}{*}{$\begin{array}{l}\text { Depth } \\
\text { (ft) }\end{array}$} & \multicolumn{4}{|c|}{ Sieve Opening Size (mm) } & \multirow{4}{*}{$\begin{array}{c}\mathrm{D}_{10} \\
(\mathrm{~mm})\end{array}$} & \multirow{4}{*}{$\begin{array}{c}\mathrm{k} \\
\text { (ft/day) }\end{array}$} \\
\hline & 0.425 & 0.15 & 0.075 & $<0.075$ & & \\
\hline 0 & \multirow{2}{*}{\multicolumn{4}{|c|}{ Vertical Grain Size Distribution (\%) }} & & \\
\hline 25 & & & & & & \\
\hline 30 & 0.42 & 5.18 & 84.60 & 9.80 & 0.075 & 16.13 \\
\hline 35 & 0.36 & 6.40 & 73.60 & 19.70 & 0.075 & 16.13 \\
\hline 40 & 0.33 & 18.50 & 58.10 & 23.10 & 0.07 & 14.11 \\
\hline 45 & 0.33 & 14.10 & 71.43 & 14.24 & 0.065 & 12.15 \\
\hline 50 & 4.19 & 74.71 & 15.62 & 4.82 & 0.07 & 14.11 \\
\hline 55 & 38.42 & 51.26 & 7.10 & 3.26 & 0.1 & 29.86 \\
\hline 60 & 0.24 & 68.05 & 29.28 & 2.22 & 0.12 & 41.47 \\
\hline 65 & 46.46 & 46.09 & 5.34 & 2.11 & 0.14 & 56.45 \\
\hline 70 & 0.34 & 65.54 & 32.82 & 1.35 & 0.15 & 68.8 \\
\hline 75 & 11.20 & 73.35 & 14.40 & 1.34 & 0.15 & 64.8 \\
\hline
\end{tabular}

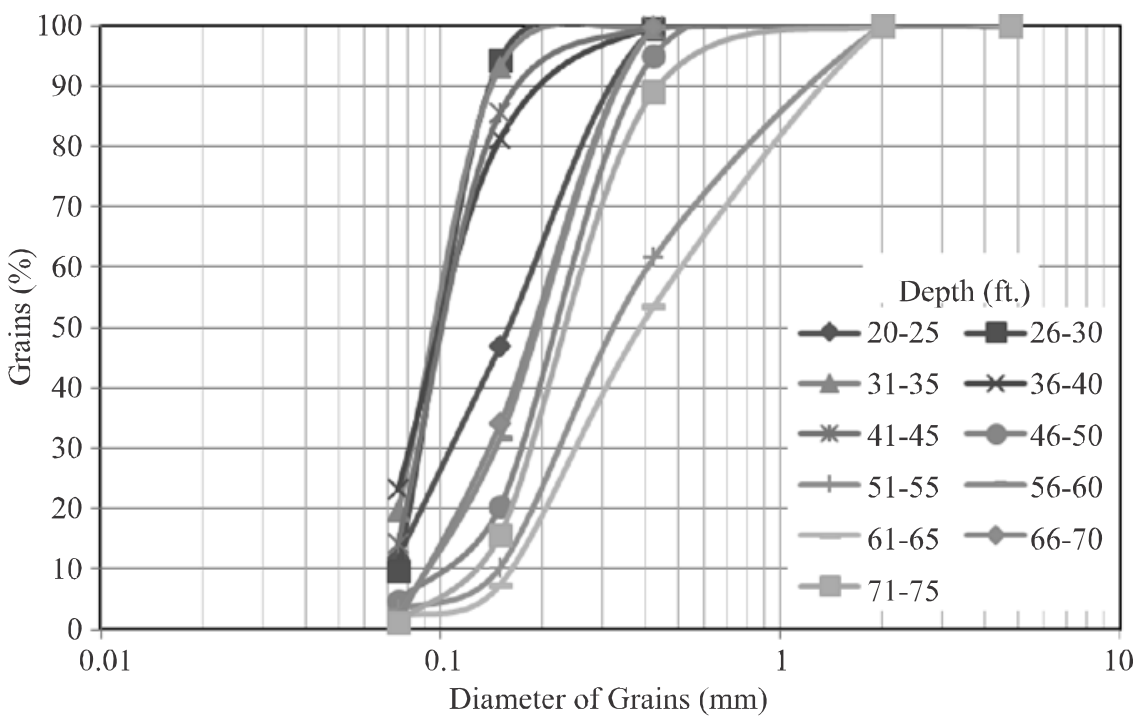

FIG. 5. GRAIN SIZE DISTRIBUTION CURVE FOR MW-04 
during the summer was $115 \mathrm{mgCaCO}_{3} / \mathrm{L}$, during the winter season it decreases to $72 \mathrm{mg} \mathrm{CaCO}_{3} / \mathrm{L}$. A similar trend was observed for the alkalinity of the Model Wells that in the summer, alkalinity was in the range of $200-300 \mathrm{mg} \mathrm{CaCO}_{3} /$ $\mathrm{L}$, whereas in winter it ranges from $30-90 \mathrm{mg} \mathrm{CaCO} / \mathrm{L}$. Thus, revels that the alkalinity of the ground water increases as the result of the bank filtration, which is in the correspondence to the results of the Sharma, et. al. [8]. For drinking water, WHO does not assigned the maximum limits for the alkalinity, whereas the $\mathrm{CPCB}$ (Central Pollution Control Board) of India has set the alkalinity limit of $500 \mathrm{mg} \mathrm{CaCO}_{3} / \mathrm{L}$ for drinking water [22]. Considering the CPCB standard all the Model Wells are delivering potable water.

\subsubsection{Total Dissolved Solids}

In the realm of public and industrial water supplies, the TDS (Total Dissolved Solids) determination is the only one of importance. It is used to determine the suitability of potential water supplies for development. The TDS contents in drinkable waters usually range from 20 $1000 \mathrm{mg} / \mathrm{L}$. In general, water with a TDS concentration less than $500 \mathrm{mg} / \mathrm{L}$ is mostly required for domestic purpose. WHO guideline values recommend the upper limit of $1000 \mathrm{mg} / \mathrm{L}$ as TDS in drinkable waters.
The concentration of the TDS in canal water and ground water during the summer and winter seasons is shown in Fig. 7. River water contains TDS concentrations at $250 \mathrm{mg} /$ $\mathrm{L}$ during the low flow of river water, i.e. in the winter season. In comparison to the summer, Rao [21] also observed the higher concentration of TDS in postmonsoon (winter). During the high flow of the river, i.e. during the summer was $210 \mathrm{mg} / \mathrm{L}$ TDS concentration in water samples. The seasonal variations in TDS concentration indicate the dilution of the river water in summer, when the flow of water is more as compared to the winter season. The river at the Kotri barrage up-stream acts as gaining river which receives the water from infiltration galleries along the banks of the river which contain appreciable amounts of TDS.

The concentration of TDS for the model wells in summer season was in the range of $250-425 \mathrm{mg} / \mathrm{L}$, which show that water from all the Model Wells was potable in the summer season as its concentration is lower than to the maximum allowable concentration of the $1000 \mathrm{mg} / \mathrm{L}$ as given per given standard of the WHO. Similarly, the concentration of the TDS in model wells in the winter season was also less than the $500 \mathrm{mg} / \mathrm{L}$, except the MW04 that has the concentration of $1110 \mathrm{mg} / \mathrm{L}$. The TDS concentration in the MW-04 indicates the underground

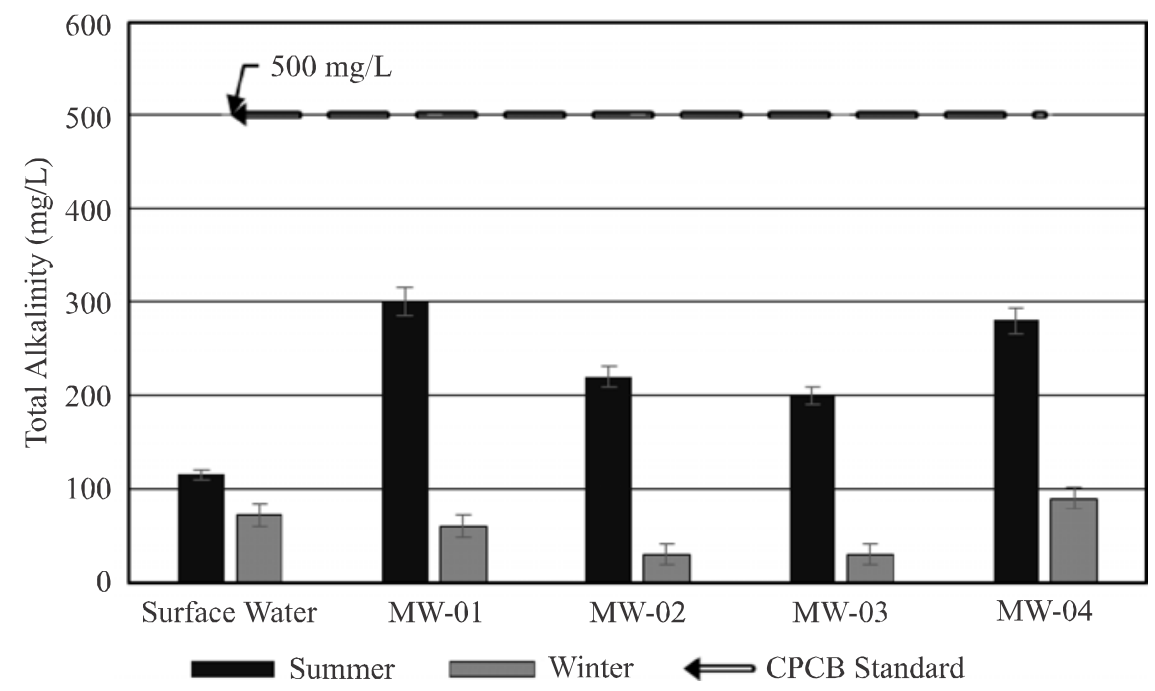

FIG. 6. SEASONAL VARIATION OF TOTAL ALKALINITY OF CANAL SURFACE WATER AND MODEL WELLS' GROUND WATER 
saline water mixing at the point, the placement of the MW04 is at the 70-80ft. depth vertical from the surface. The highest concentration of the MW-04 was might be because of the various domestic wastewaters, which are being added into the canal waters at the up-stream of the MW04. Soomro, et. al. [23] also concluded that the groundwater contamination of the heavy metals increases towards the downstream. Present study also follows the observation of Rao [21] that as the groundwater table increases, the concentration of TDS decreases. Moreover, through Fig. 7 it can also be observed that the depth of the model wells is directly proportional to the concentration of the total dissolved salts. Furthermore, the layer of fine grained sediments is considered to be the site of most of the improvements of the water quality that occur at bank filtration sites [24]. Referring to Table 5, as the hydraulic conductivity of the MW-04 is higher and the grain size distribution is lower, and thus affects the TDS removal.

\subsubsection{Chloride}

Surface and ground water generally have a substantial quantity of chloride and is not injurious to people. At higher concentrations above $250 \mathrm{mg} / \mathrm{L}$, it offers a brackish taste of water, which is offensive to users. Due to this purpose a standard of $250 \mathrm{mg} / \mathrm{L}$ for chloride in drinking water has been set in WHO guideline values for drinking water. In many areas the concentration of chloride in usual waters is a significant thoughtfulness in the selection of deliveries for human consumption, industrial uses and agricultural purpose. The determination of chloride is also used to govern pumping of ground water from sites where disturbance of saline water is a problem.

The concentration of the chloride in canal water and ground water during the summer and winter seasons is shown in Fig. 8. During the summer season, the concentration of the chloride in the canal water was observed as $90 \mathrm{mg} / \mathrm{L}$ due to dilution, whereas it increases to $114 \mathrm{mg} / \mathrm{L}$ during winter season. The concentration of chloride for the model wells in the summer season was in the range of $60-120 \mathrm{mg} / \mathrm{L}$, which show that water from all the Model Wells was potable in the summer season as its concentration is lower than to the maximum allowable concentration of the $250 \mathrm{mg} / \mathrm{L}$ as given per given standard of the WHO. Similarly, the concentration of the chloride in Model Wells in the winter season was also less than the $250 \mathrm{mg} / \mathrm{L}$, except the MW-04 that has the concentration of $324 \mathrm{mg} / \mathrm{L}$. The chlorides concentration in the MW-04 indicates the underground saline water mixing at the point, the placement of the MW-04 is at the 70-80 ft. depth vertical from the surface. These results are in

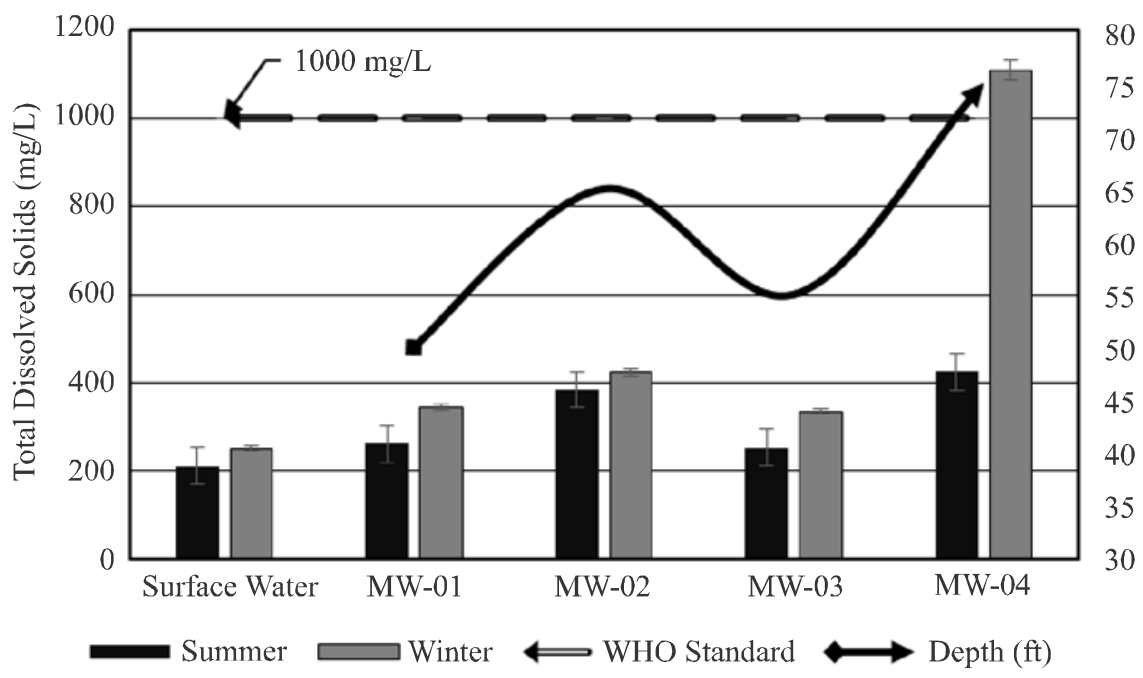

FIG. 7. SEASONAL VARIATION OF TOTAL DISSOLVED SOLIDS IN CANAL SURFACE WATER AND MODEL WELLS' GROUND WATER

Mehran University Research Journal of Engineering \& Technology, Volume 35, No. 3, July, 2016 [p-ISSN: 0254-7821, e-ISSN: 2413-7219] 
correspondence with the literature $[21,25]$ that the concentration of the chlorides increases in the postmonsoon season (winter). The highest concentration of the MW-04 was might be because of the various domestic wastewaters, which are being added into the canal waters at the up-stream of the MW-04. Furthermore, like the TDS, Fig. 8 show that the depth of the model wells is directly proportional to the concentration of the chlorides in the groundwater.

\subsubsection{Sulfate}

Sulfate is the major anions arising in water bodies, and is objectionable due to its intensive effect on humans when it is available in higher concentrations. The WHO standard for sulfate is $250 \mathrm{mg} / \mathrm{L}$ for drinking water. Sulfate is significant in both public and industrial water deliveries, due to the affinity of the water having considerable quantities to form solid scales in heat exchangers and boilers.

The concentration of the sulfate in canal water and ground water during the summer and winter seasons is shown in Fig. 9. The sulfate concentration in canal water during the summer season was $116 \mathrm{mg} / \mathrm{L}$, which decreases to $85 \mathrm{mg} / \mathrm{L}$ in winter. The concentration of sulfate for the model wells in the summer season was in the range of 88-
$150 \mathrm{mg} / \mathrm{L}$, which show that water from all the Model Wells was potable in the summer season as its concentration is lower than to the maximum allowable concentration of the $250 \mathrm{mg} / \mathrm{L}$ as given per given standard of the WHO. Similarly, the concentration of the sulfate in model wells in the winter season was also lower than the $250 \mathrm{mg} / \mathrm{L}$, except the MW-04 that has the concentration of $700 \mathrm{mg} /$ $\mathrm{L}$. The highest concentration of the MW-04 was might be because of the various domestic wastewaters, which are being added into the canal waters at the up-stream of the MW-04. Furthermore, like the total dissolved solids and chlorides, Fig. 9 show that the depth of the model wells is directly proportional to the concentration of the sulfates in the groundwater.

\subsubsection{Nitrate-Nitrogen $\left(\mathrm{NO}_{3}-\mathrm{N}\right)$}

The composites of nitrogen are of significant importance not only in the humans, but also in the living of all animals and plants. The higher concentration of nitrate in drinking water usually is the reason of methemoglobinemia in newborns. For this reason in public water supplies, WHO had set an allowable concentration of nitrate-nitrogen maximum of $10 \mathrm{mg} / \mathrm{L}$.

The concentration of the nitrate in canal water and ground water during the summer and winter seasons is shown in

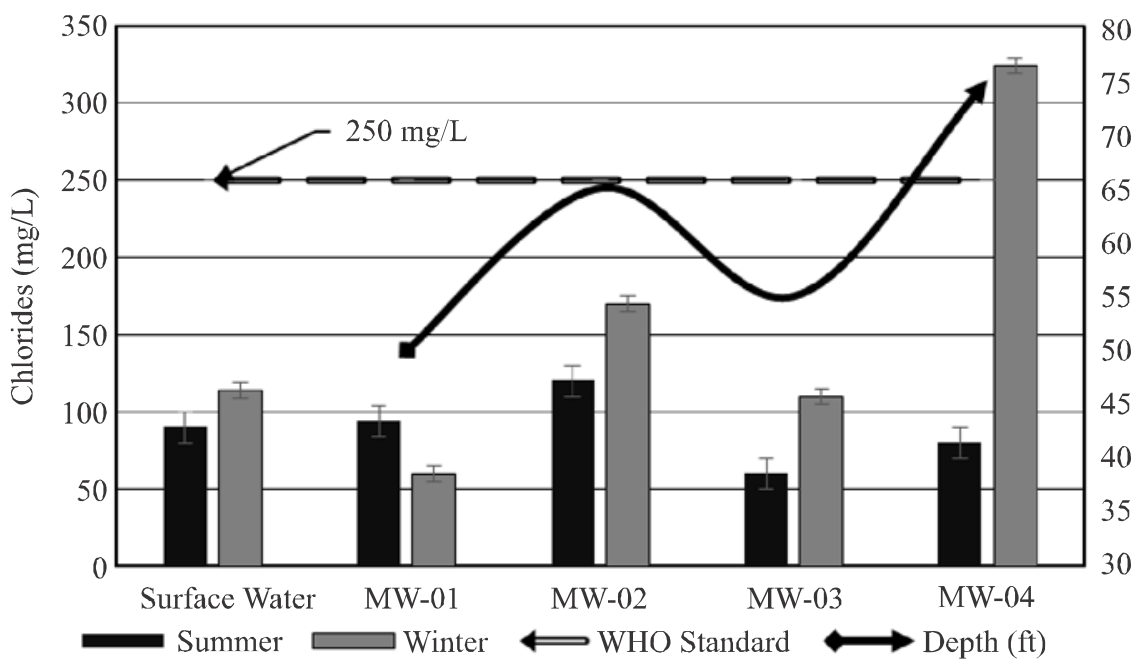

FIG. 8. SEASONAL VARIATION OF CHLORIDES OF CANAL SURFACE WATER AND MODEL WELLS' GROUND WATER

Mehran University Research Journal of Engineering \& Technology, Volume 35, No. 3, July, 2016 [p-ISSN: 0254-7821, e-ISSN: 2413-7219] 
Fig. 10. The result of the canal water in summer season was $12.2 \mathrm{mg} / \mathrm{L}$, whereas in the winter season it decreases to $3.5 \mathrm{mg} / \mathrm{L}$. The fertilizers and return flows from irrigated land are the major sources of nitrate ions in the surface water and ground water [26]. The highest concentration of the nitrate in the summer season in the study area was because of the agricultural waste run-off, when Indus River receives storm water from the upper catchment area of the country. A higher concentration of the nitrogen is also caused by the disposal of the wastewater as reported by Leghari, et. al. [27].

The concentration of nitrate in the model wells in the summer season was in the range of 1.1-1.2 mg/L, which show that water from all the Model Wells was potable in the summer season as its concentration is lower than to the maximum allowable concentration of the $10 \mathrm{mg} / \mathrm{L}$ as given per given standard of the WHO. Similarly, the concentration of nitrate in the model wells in winter season was also low and was in the range of $0.2-0.9 \mathrm{mg} / \mathrm{L}$. Thus, it reveals that the Model Wells filters the nitrates to the allowable range. Moreover, the results also reveal that the nitrate of the ground water decreases as the result of the bank filtration, which is in the correspondence to the results of the Sharma, et. al. [8] as well as Giridharan, et. al. [28].

\subsubsection{Total Iron}

Regarding the weight, iron is the utmost plentiful element in the earth's crust. Iron is a vital element in the human diet. Regardless of universal distribution in plenty, natural water has variable quantities of iron [29].

The concentration of the iron in canal water and ground water during the summer and winter seasons is shown in Fig. 11. The concentration of iron in the summer was higher $1.89 \mathrm{mg} / \mathrm{L}$ than in the winter as $0.11 \mathrm{mg} / \mathrm{L}$ in samples of canal water during the period of study. Moreover, the concentration of iron in all the Model Wells is lower than to the maximum allowable limit by WHO as $0.3 \mathrm{mg} / \mathrm{L}$. The results reveal that the Model Wells decreases the concentration of the iron and thus show their suitability to be used as the natural method to get water purified. Moreover, the results also reveal that the iron in the ground water decreases as the result of the bank filtration, which is in the correspondence to the results of the Sharma, et. al. [8]. Furthermore, unlike the TDS, chlorides and sulfates, Fig. 11 show that the depth of the model wells is indirectly proportional to the concentration of the total iron in the groundwater.

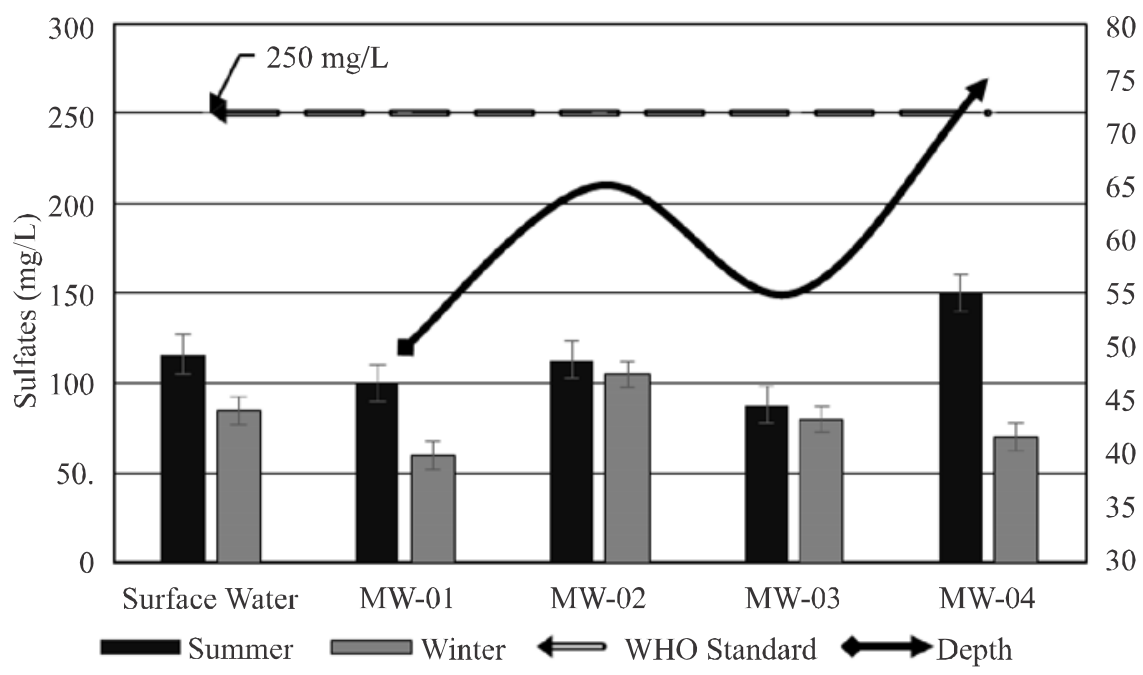

FIG. 9. SEASONAL VARIATION OF SULFATE OF CANAL SURFACE WATER AND MODEL WELLS' GROUND WATER 


\subsection{7 pH}

The values of $\mathrm{pH}$ in canal water and ground water during the summer and winter seasons are shown in Fig. 12. As per the results, all the $\mathrm{pH}$ values of canal water and ground water during the summer and winter seasons were observed higher than to the LL (Lower Limit) as standardized by the WHO, but are lower than the UL (Upper Level). The $\mathrm{pH}$ variations at the different points may be due to the weak mineral acid and the decomposition of the organic matter, which produces the carbon dioxide that increase the amount of carbonic acid by bacterial respiration within the aquifer. Regarding the seasonal variation, the $\mathrm{pH}$ is not a significant parameter as also observed by Rao [21]. Moreover, it was also observed that the bank filtration slightly decreases the $\mathrm{pH}$ value of the water. Thus, it reveals that the bank filtration slightly decreases the $\mathrm{pH}$ of the water, which is in correspondence to the results of the Heberer, et. al. [30].

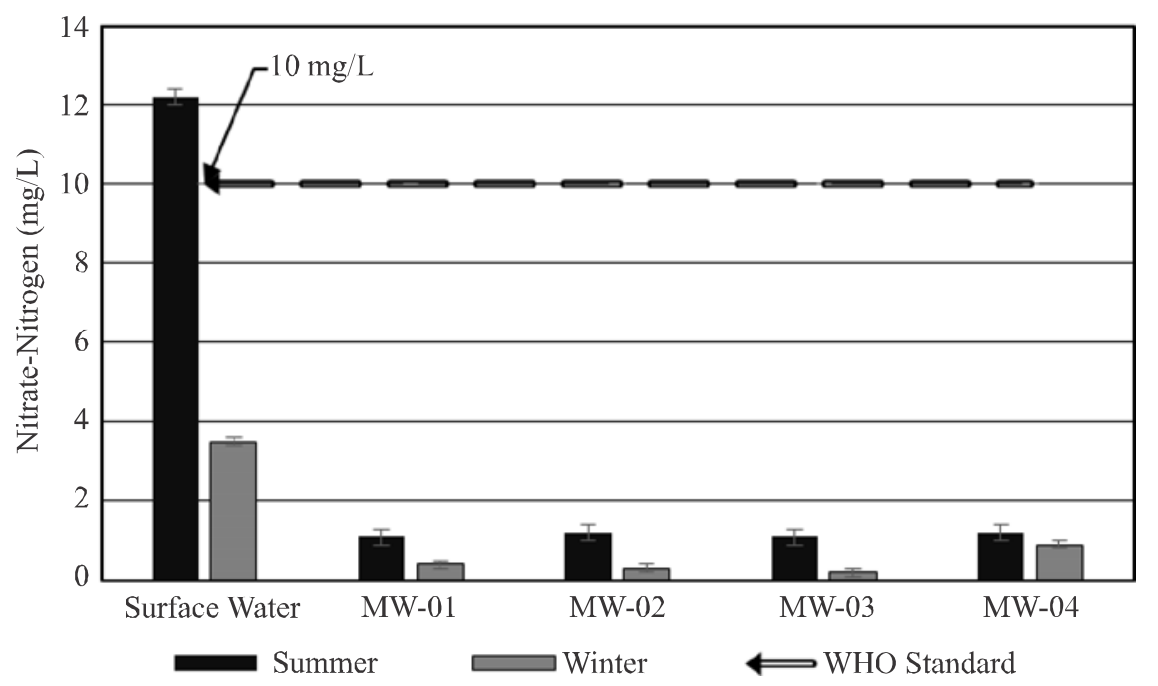

FIG. 10. SEASONAL VARIATION OF NITRATE OF CANAL SURFACE WATER AND MODEL WELLS' GROUND WATER

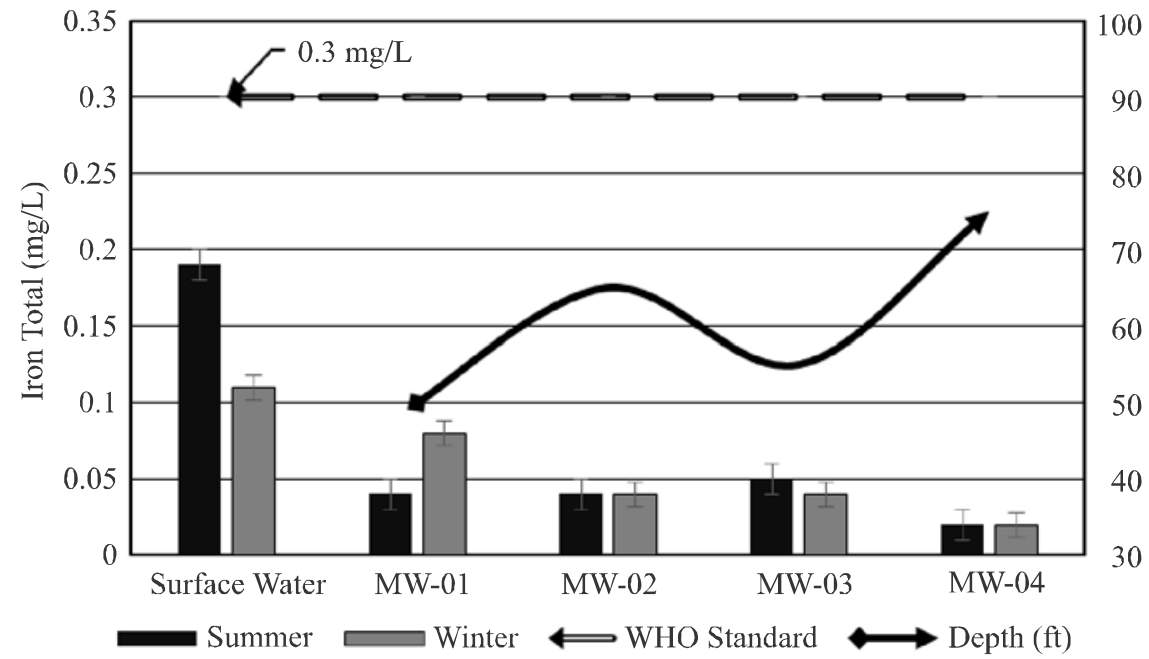

FIG. 11. SEASONAL VARIATION OF TOTAL IRON OF CANAL SURFACE WATER AND MODEL WELLS' GROUND WATER

Mehran University Research Journal of Engineering \& Technology, Volume 35, No. 3, July, 2016 [p-ISSN: 0254-7821, e-ISSN: 2413-7219] 


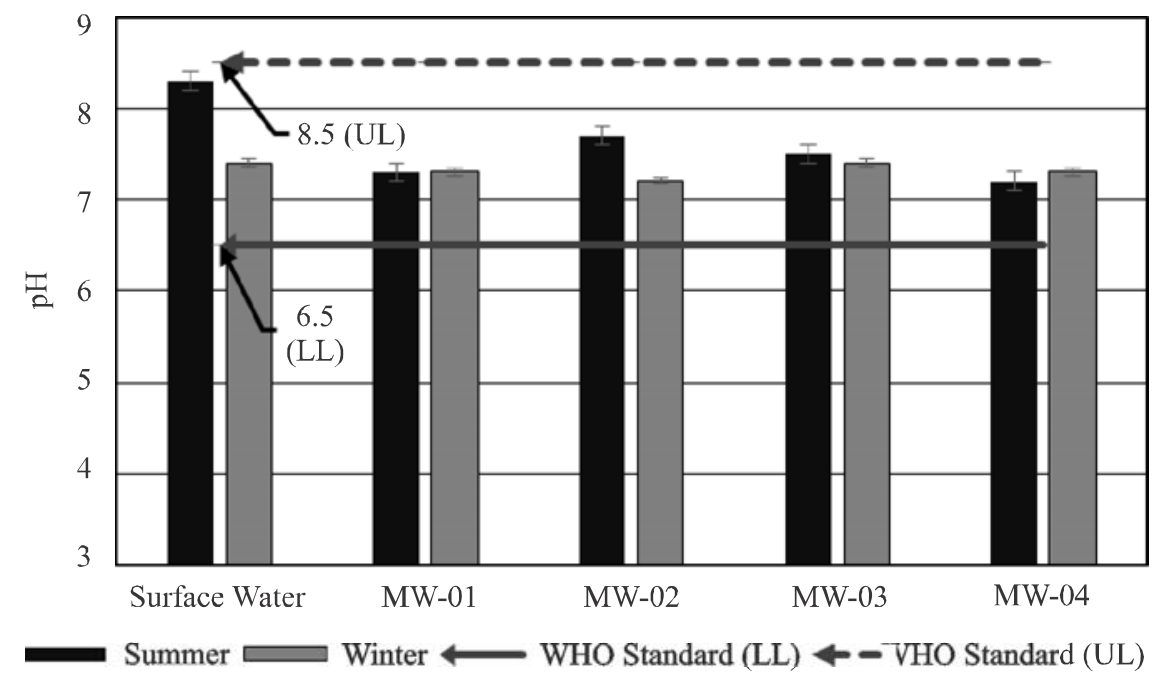

FIG. 12. SEASONAL VARIATION OF PH OF CANAL SURFACE WATER AND MODEL WELLS' GROUND WATER

\section{CONCLUSIONS}

Ground water is influenced by the grain size distribution and the location of the model Wells. The model well that has a higher percentage of the $0.075 \mathrm{~mm}$ grain size distribution (hydraulic conductivity from 10-25 ft/day) was more suitable for the filtration of the canal water through its banks, followed by $0.15 \mathrm{~mm}$ of grain size distribution (hydraulic conductivity $>25 \mathrm{ft} /$ day). The total alkalinity, sulfate, total iron and $\mathrm{pH}$ of all model wells were in the safe range. The nitrate-nitrogen of surface water in summer was observed higher than the standard value $(10 \mathrm{mg} / \mathrm{L})$, but all the wells have lower concentrations of nitrate-nitrogen, which reveals that the bank filtration is suitable to remove the nitrate-nitrogen. One of the model well, i.e. MW-04 has shown higher concentrations of the TDS and chloride. The increase in chemical concentration in MW-04 was observed during the low-flow season of canals (winter). Besides this, in comparison to the surface water, almost all selected parameters of water showed slightly higher concentrations during the winter season. The results of the three model wells MW-01, MW-02, and MW-03 have shown chemical concentrations within WHO guideline values for drinking water during both seasons. The hydraulic conductivity affects the quality of water filtered through bank filtration and is influenced by the grain size distribution. Moreover, the concentration of TDS, chloride, sulfate and total iron increase with the depth of the well.

The present study reveals that the canal water filtration is highly suitable to get the potable water at the upstream of the canal during the summer season.

\section{ACKNOWLEDGEMENT}

The authors are wishing to acknowledge Mehran University of Engineering \& Technology, Jamshoro, Sindh, Pakistan, for its support to carry out this research work.

\section{REFERENCES}

Mulla, J.G., Asif, S., Abed, S., and Vidya, P., "Ground Water Quality Assessment of Babalgaon, District Latur”, Journal of Chemical Physics, Volume 2, No. 1, pp. 501-504, 2012.

[2] Kandhar, I.A and Ansari, A.K, "Drinking Water Quality of Hyderabad City", Proceedings of $24^{\text {th }}$ Conference on Water and Sanitation for All, pp. 254-257, Islamabad, 1998.

[3] WHO (World Health Organization), "Guidelines for Drinking-water Quality”, 4th Edition, 2011. 
[4] Wattoo, M.H.S, Wattoo, F.H, Trimizi, S.A, Kazi, T.G, Bhanger, M.I, Mahar, R.B., and Iqbal, J., "Quality Characterization of Phuleli Canal Water for Irrigation Purpose", Journal of Nucleus, Volume 41, Nso. 1-4, pp. $69-75,2000$

Mark, A., Shannon, P.W.B, Menachem, E., John, G., Georgiadis, B.J.M., and Anne, M.M., "Science and Technology for Water Purification in the Coming Decades", Nature, Volume 452, pp. 301-310, 2008.

Ashok, G., "Drinking Water in Developing Countries", Annual Review of Energy and the Environment, Volume 23, pp. 253-286, 1998.

Alexandra, A.G., Katy, A.H., and Kerry, T.B.M., "River Sediment and Flow Characteristics Near A Bank Filtration Water Supply: Implications For Riverbank Clogging", Journal of Hydrology, Volume 344, Nos. 1-2, pp. 55-69, 2007.

[8] Sharma, L., Greskowiak, J., Ray, C., Eckert, P., and Prommer, H., "Elucidating Temperature Effects on Seasonal Variations of Biogeochemical Turnover Rates during Riverbank Filtration”, Journal of Hydrology, Volume 428-429, pp. 104-115, 2012.

Ray, C., Grischek, T., Schubert, J., Wang, J.Z., and Speth, T.F., "A Perspective of Riverbank Filtration”, Journal of American Water Works Association, Volume 94, No. 4, pp. 149-160, 2002.

[10] Hiscock, K.M., and Grischek, T., "Attenuation of Groundwater Pollution by Bank Filtration”, Journal of Hydrology, Volume 266, Nos. 3-4, pp. 139-144, 2002.

[11] Kuehn, W., and Mueller, U., "River Bank Filtration An Overview", Journal of American Water Works Association, Volume 92, No. 12, pp. 60-69, 2000.

[12] Wang, J.Z., Hubbs, S.A., and Song, R. "Evaluation of Riverbank Filtration as a Drinking Water Treatment Process", Research Foundation and American Water Works Association, Denver, CO, USA, 2000.

[13] Massmann, G., Nogeitzig, A., Taute, T., and Pekdeger, A, "Seasonal and Spatial Distribution of Redox Zones during Lake Bank Filtration in Berlin", Journal of Environmental Geology, Volume 54, No. 1, pp. 53-65, 2008.
Ray, C., "Modeling RFB Efficiency for Mitigation Chemical Shock Loads", Journal of American Water Works Association, Volume 96, No 5, pp. 114-128, 2004.

[15] Hari, P.K., Ojha.C., Nirala, R., and Sharma, D., "Optimal Well Location in a River Bank Filtration System: Sensitivity to Aquifer Characteristics and Decay Rate", Journal of Hazardous, Toxic, and Radioactive Waste, DOI: 10.1061/(ASCE)HZ.2153-5515.0000307, 2016.

[16] Doussan, C., Ledoux, E., and Detay, M., "River-Groundwater Exchanges, Bank Filtration, and Groundwater Quality: Ammonium Behavior", Journal of Environmental Quality, Volume 27, No. 6, pp. 1418-1427, 1998.

[17] ASTM D6913-04, "Standard Test Methods for ParticleSize Distribution (Gradation) of Soils Using Sieve Analysis”, ASTM International, West Conshohocken, PA, www.astm.org, 2009.

[18] Hazen, A., "Some Physical Properties of Sand and Gravels", Massachusetts State Board of Health, $24^{\text {th }}$ Annual Report, 1893.

[19] APHA, (American Public Health Association), "Standard Methods for the Examination of Water and Wastewater", 2012 .

[20] Hubbs, S.A., "Evaluation Streambed Forces Impacting the Capacity of Riverbed Filtration Systems", Chapter2, Hubbs, S. A., and NATO Public Diplomacy Division, Riverbank Filtration Hydrology Dordrecht, Great Britain, Springer, 2006.

[21] Rao, N.S., "Seasonal Variation of Groundwater Quality in a Part of Guntur District, Andhra Pradesh, India", Environmental Geology, Volume 49, pp. 413-429, 2006.

[22] Kumar, M., and Puri, A., "A Review of Permissible Limits of Drinking Water", Indian Journal of Occupational and Environmental Medicine, Volume 16, No. 1, pp. 40-44, 2012 .

[23] Soomro, A., Siyal, A.A., Mirjat, M.S., and Sial, N.B., "Seasonal Variability of Trace and Heavy Metals Concentration in Groundwater and its Quality for Drinking and Irrigation Purpose under Phuleli Canal Command Area (Sindh), Pakistan", Journal of Basic \& Applied Sciences, Volume 9, pp. 550-561, 2013. 
[24] US EPA, Federal Register, "Long Term to Enhanced Surface Water Treatment Rule", Environmental Protection Agency Rules and Regulations, Volume 71, No. 3, pp. 654-786, 2006.

[25] Gowd, S.S., “Assessment of Groundwater Quality for Drinking and Irrigation Purposes: A Case Study of Peddavanka Watershed, Anantapur District, Andhra Pradesh, India”, Environmental Geology, Volume 48, pp. 702-712, 2005.

[26] Rao, S.N., "Geochemistry of Groundwater in Parts of Guntur District, Andhra Pradesh, India”, Environmental Geology, Volume 41, pp. 552-562, 2002.

[27] Leghari, A., Chandio, S.N., Khuhawar, M.Y., Jahangir, T.M., and Leghari, S.M., "Physico-Chemical Study and Budgeting of Wastewater from Hyderabad City Limits", Journal of Biological Science, Volume 4, pp. 317-22, 2004 .
[28] Giridharan, L., Venugopal, T., and Jayaprakash, M., "Evaluation of the Seasonal Variation on the Geochemical Parameters and Quality Assessment of the Groundwater in the Proximity of River Cooum, Chennai, India", Environmental Monitoring and Assessment, Volume 143, pp. 161-178, 2008.

[29] FAO/WHO, "Requirement of Vitamin A, Iron, Folate and Vitamin B12", Report of a Joint FAO/WHO Expend Consultation Rome, Food and Agricultural Organization of the United Nations, FAO Food and Nutrition Series No. 23, 1988.

[30] Heberer, T., Ingrid, M., Verstraeten, M.T.M., Andy, M., and Kirsten, R., "Occurrence and Fate of Pharmaceuticals during Bank Filtration - Preliminary Results from Investigations in Germany and the United States", Journal of Contemporary Water Research and Education, Volume 120, No. 1, pp. 1-17, 2001. 